\title{
ELECTRON MICROSCOPIC RADIOAUTOGRAPHIC LOCALIZATION OF IODINATED NERVE GROWTH FACTOR BOUND TO AND INTERNALIZED BY PC12 CELLS ${ }^{1}$
}

\author{
PAULETTE BERND ${ }^{2}$ AND LLOYD A. GREENE \\ Department of Pharmacology, New York University Medical Center, New York, New York 10016
}

Received June 21, 1982; Revised September 13, 1982; Accepted September 15, 1982

\begin{abstract}
Nerve growth factor (NGF) has many effects on sympathetic and sensory neurons, but the mechanisms by which NGF exerts its actions are unknown. We have determined the localization of bound and internalized ${ }^{125}$ I-NGF by light and electron microscopic radioautography on a cell line derived from a rat pheochromocytoma (PC12). In response to NGF, PC12 cells cease mitosis and develop neuron-like processes. We have localized ${ }^{125} \mathrm{I}-\mathrm{NGF}(5 \mathrm{ng} / \mathrm{ml})$ in cells without previous exposure to NGF (naive) after a continuous incubation with ${ }^{125} \mathrm{I}$-NGF for $2 \mathrm{~min}, 1 \mathrm{hr}, 6 \mathrm{hr}, 1$ day and 1 week, as well as in cells that were grown with NGF $(50 \mathrm{ng} / \mathrm{ml})$ for 1 week (primed) and then exposed to ${ }^{125} \mathrm{I}$-NGF for $15 \mathrm{~min}, 1 \mathrm{hr}, 6 \mathrm{hr}$, and 1 day. Examination of whole mount radioautographs revealed that all cells were labeled and that the distribution of grains was homogeneous. Primed cells were labeled on neurites and growth cones, as well as on cell bodies, and also had a greater density of labeling than naive cells. These patterns were identical for all time points studied, with the exception that "hot spots" of radioactivity appeared along neurites following a long incubation with ${ }^{126}$ I-NGF (longer than $6 \mathrm{hr}$ ). Electron microscopic radioautography revealed that these "hot spots" correspond to accumulation of grains in aggregates of lysosomes. The binding of ${ }^{125} \mathrm{I}-\mathrm{NGF}$ was specific, since control cultures (excess nonradioactive NGF) exhibited only background levels of grains. Quantification of electron microscopic radioautographs revealed that 70 to $95 \%$ of the grains were internalized after $15 \mathrm{~min}$. The only cellular components labeled above random distribution levels were the plasma membrane, lysosomes, and the nuclear membrane. Each of these structures exhibited "down-regulation" of specific binding in naive cells after $6 \mathrm{hr}$ of incubation. The cytosol, polyribosomes, dense cored granules, heterochromatin, and euchromatin showed labeling at or below the levels expected from random distribution of grains within the cell. The distribution of grains about the nuclear membrane also suggested an association with ${ }^{125} \mathrm{I}-\mathrm{NGF}$. These data indicate that a large proportion of NGF "bound" to target cells is in fact internalized, and are consistent with some, but not other models for NGF's mechanism of action.
\end{abstract}

The effects of nerve growth factor (NGF) on developing sympathetic and sensory ganglia are many and varied (see reviews of Levi-Montalcini and Angeletti, 1968; Bradshaw, 1978; and Greene and Shooter, 1980; Thoenen and Barde, 1980). It is not known, however, what mechanisms of action are involved in exerting these effects.

\footnotetext{
${ }^{1}$ We thank Dr. Michael D. Gershon and Ms. Diane Sherman for sharing their expertise in the technique and analysis involved in clectron microscopic radioautography, Dr. Fred Maxfield for his helpful discussion, and Ms. Margaret DiPiazza for assistance. This study was supported by National Institutes of Health Grant NS 16036, March of Dimes Grant 1-704, and a Pharmaceutical Manufacturers Association Foundation Fellowship to P. B. L. A. G. was partially supported by a Career Award from the Irma T. Hirschl Trust.

${ }^{2}$ To whom correspondence should be sent at her present address: Department of Anatomy, Mt. Sinai School of Medicine, 1 Gustave Levy Place, New York, NY 10029.
}

There is abundant evidence that sympathetic and sensory neurons possess specific receptors for NGF on their plasma membranes and that bound NGF is subsequently internalized, and if taken up at nerve endings, retrogradely transported (see reviews of Bradshaw, 1978; Greene and Shooter, 1980; and Thoenen and Barde, 1980). The role of such internalization in the actions of NGF is unknown.

One means to explore the significance of NGF internalization is to determine the intracellular distribution of the factor following its uptake. This has been approached by various investigators using both biochemical and morphological methods. Andres et al. (1977) showed the presence of NGF binding in a 'Triton-insoluble fraction in embryonic chick dorsal root ganglia neurons. Further subcellular fractionation indicated that this binding was associated with the nucleus and in particular with nuclear 
chromatin. Yankner and Shooter (1979) also detected Triton-insoluble binding in a clonal rat pheochromocytoma cell line (PC12; Tischler and Greene, 1975; Greene and Tischler, 1976). This nuclear binding increased with time, and after $17 \mathrm{hr}$ of incubation with ${ }^{125} \mathrm{I}-\mathrm{NGF}$, approximately $60 \%$ of the total NGF binding associated with the cell was assigned to the nuclear fraction. In contrast to the findings of Andres et al. (1977), the nuclear receptors were reported to be localized to the nuclear membrane. In addition to this evidence, subcellular fractionation of cells that had retrogradely transported NGF indicated that 20 to $30 \%$ of the factor was present in the nuclear fraction (Stockel et al., 1976; Johnson et al., 1978). Yet another set of studies (Nasi et al., 1982) has been interpreted to suggest that internalized NGF may directly interact with several elements of the cytoskeleton.

Morphological studies have not necessarily corroborated such biochemical findings and have themselves been somewhat inconsistent. Retrogradely transported ${ }^{125}$ I-NGF or NGF coupled to horseradish peroxidase was localized to smooth endoplasmic reticulum, vesicles, and lysosomes, but not to the nucleus (Schwab, 1977; Schwab and Thoenen, 1977). Marchisio et al. (1980) employed whole mount radioautography and immunofluorescence to localize NGF bound to PC12 cells and suggested that there was a perinuclear and nucleolar accumulation of NGF within a few hours of initial binding. A similar study with cultured embryonic chick sympathetic neurons indicated a cytoplasmic and paranuclear, but not nuclear, distribution of NGF in whole mounts and 1- $\mu \mathrm{m}$ sections (Marchisio et al., 1981). Finally, in a recent electron microscopic radioautographic study on retrogradely transported ${ }^{125} \mathrm{I}-\mathrm{NGF}$ (up to $24 \mathrm{hr}$ of incubation) in cultured rat sympathetic neurons, the only intracellular structures showing significant accumulation of NGF were the lysosomes (Claude et al., 1982).

NGF appears to have multiple actions on its target cells; some of these actions require gene transcription and some do not (Greene and Shooter, 1980). Because of the complexity of these cellular responses, it might be that the fate of internalized NGF is also varied, particularly in a temporal sense. Therefore, we have sought here to determine, by means of light and electron microscopic radioautography, the localization of NGF within a target cell after various times and conditions of exposure.

To carry out this study, we chose the PC12 line of rat pheochromocytoma cells. These cells have specific plasma membrane receptors for NGF and respond to the protein in many ways, including the transition from a dividing chromaffin cell-like phenotype to a nondividing sympathetic neuron-like phenotype (Greene and Tischler, 1976, 1982). Since PC12 cells do not require NGF for survival, in contrast to sympathetic neurons, they can be examined at various times without, as well as with, pre-exposure to the factor. Our study hence encompasses binding and localization with both naive (i.e., previously untreated and dividing) and "primed" (NGF-pretreated, process-bearing, and nondividing) PC12 cells.

\section{Materials and Methods}

Preparation of NGF. NGF (2.5 S) was prepared from the submandibular glands of adult male mice according to the protocol of Mobley et al. (1976). An endproduct with biological activity $\left(\mathrm{ED}_{50}\right)$ of $0.25 \mathrm{ng} / \mathrm{unit}$ was routinely obtained, as determined by the PC12 bioassay of Greene (1977).

Iodination of NGF. NGF was iodinated by the lactoperoxidase method, according to the protocol of Sutter et al. (1979). The reaction consistently yielded ${ }^{125} \mathrm{I}-\mathrm{NGF}$ that was greater than $95 \%$ precipitable with trichloroacetic acid (TCA) and had an activity of $35 \mathrm{cpm} / \mathrm{pg}$ as determined by the PC12 bioassay (Greene, 1977).

Tissue culture techniques. Culture medium consisted of 85\% Roswell Park Memorial Institute, Medium 1640 (Grand Island Biological Co., Grand Island, NY), 10\% heat-inactivated horse serum (KC Biologicals, Lenexa, $\mathrm{KA}$ ), and 5\% fetal calf serum (KC Biologicals), with 50 units $/ \mathrm{ml}$ of penicillin and 25 units $/ \mathrm{ml}$ of streptomycin (GIBCO). PC12 cells were plated either in $35-\mathrm{mm}$ polystyrene tissue culture dishes $\left(5 \times 10^{5}\right.$ cells $/$ dish; Falcon, Cockeysville, MD) that had been coated directly with rat tail collagen (Bornstein, 1958) or on glass coverslips (2 $\times 10^{5}$ cells/coverslip; $12 \mathrm{~mm}$; Rochester Scientific Co., Inc., Rochester, NY) coated with collagen via an aminosilane derivatization (modification of Gottlieb and Glaser, 1975). Some of the cultures were supplemented with 50 $\mathrm{ng} / \mathrm{ml}$ of NGF for 1 week prior to experimentation in order to obtain primed cultures exhibiting extensive neurite outgrowth. Naive cells (i.e., without NGF pretreatment) used for experiments were plated approximately 2 days in advance. Cultures were maintained at $37^{\circ} \mathrm{C}$ in a water-saturated atmosphere of $93 \%$ air and $7 \% \mathrm{CO}_{2}$. Medium was changed every 2 to 3 days.

Incubation with ${ }^{125} I-N G F$. Primed cultures (NGF pretreated) were washed several times with fresh medium that did not contain NGF over a period of $1.5 \mathrm{hr}$ immediately prior to incubation with ${ }^{125} \mathrm{I}-\mathrm{NGF}$. Solutions with ${ }^{125} \mathrm{I}-\mathrm{NGF}(5 \mathrm{ng} / \mathrm{ml}$ in the medium described above; 0.2 nM) were prepared and added to cultures following removal of most of the nonradioactive medium. Cultures were maintained as described above for various lengths of time ( $2 \mathrm{~min}, 15 \mathrm{~min}, 1 \mathrm{hr}, 6 \mathrm{hr}, 24 \mathrm{hr}$, and 1 week). Cultures maintained for 1 week included $50 \mathrm{ng} / \mathrm{ml}$ of nonradioactive NGF as a carrier and were refed with fresh medium every 2 to 3 days. Control cultures contained a 1000-fold excess of nonradioactive NGF (5 $\mu \mathrm{g} /$ $\mathrm{ml}$ ) in addition to the ${ }^{125} \mathrm{I}-\mathrm{NGF}$. The ratio of displaceable to nondisplaceable binding ranged from 20:1 to 5:1 for times up to $6 \mathrm{hr}$ of incubation and was approximately $2: 1$ for cultures incubated with label for $24 \mathrm{hr}$. Following incubation, cultures were rapidly washed six times (within $30 \mathrm{sec}$ ) with phosphate-buffered saline $\left(4^{\circ} \mathrm{C}\right.$; PBS) and fixed ( $3 \%$ glutaraldehyde in $0.1 \mathrm{~m}$ potassium phosphate buffer, $\mathrm{pH} 7.5$, containing $3 \%$ sucrose for 45 min at room temperature. Cultures were then washed three times with $0.1 \mathrm{M}$ potassium phosphate buffer containing $3 \%$ sucrose prior to processing for radioautography.

Light microscopic radioautography. Glass coverslips were removed from the buffer described above, mounted on a glass slide (cells up) using Permount (Fisher Scientific Co., Pittsburgh, PA), and allowed to dry. After 2 to 3 days the coverslips were securely mounted and the slides were rinsed for $1 \mathrm{hr}$ under running tap water and then allowed to dry. Slides were dipped in Ilford L4 
emulsion (1:1 dilution in water; Polysciences, Inc, Warrington, $\mathrm{PA}$ ), air dried, and stored in light-tight boxes, containing dessicant, at $4^{\circ} \mathrm{C}$. Slides were exposed for 1 , 4, and 8 weeks, developed in D-19 (Eastman Kodak Co., Rochester, NY), and fixed. Glass coverslips were mounted with glycerin on the coverslips containing cells, and cultures were examined with phase and bright-field microscopy.

Analysis of radioactivity within cells. In order to determine whether the radioactivity contained within cells was NGF or a breakdown product, the cell extracts from various time points of ${ }^{125} \mathrm{I}-\mathrm{NGF}$ incubation ( $15 \mathrm{~min}$, $1 \mathrm{hr}, 6 \mathrm{hr}, 1 \mathrm{day})$ were analyzed. The cultures were washed six times with PBS, suspended in electrophoresis sample buffer, and boiled, as described by McGuire and Greene (1980). Aliquots were precipitated with $10 \%$ TCA to determine the percentage of radioactivity in macromolecular form. The remainder of the samples (approximately 3000 to $5000 \mathrm{cpm}$ each) were run on $15 \%$ polyacrylamide slab gels using the discontinuous buffer system of Laemmli (1970). After electrophoresis at room temperature for about $3.5 \mathrm{hr}$ at $35 \mathrm{~mA}$, gels were fixed overnight in 50\% methanol and $10 \%$ glacial acetic acid. Gels were dried under heat and vacuum and exposed to Kodak XR-5 x-ray film for 2 weeks. ${ }^{125} \mathrm{I}-\mathrm{NGF}$, as well as nonradioactive NGF, was used as a standard. Cell number was determined by dissolving the cells in $0.2 \%$ Nonidet P40 detergent (Particle Data Laboratories, Ltd., Elmhurst, IL) and counting the nuclei in a hemacytometer.

Electron microscopic radioautography. Fixed cells in $35-\mathrm{mm}$ dishes were postfixed in osmium tetroxide ( $1 \%$ in $0.1 \mathrm{~m}$ potassium phosphate buffer containing $3 \%$ sucrose for $1 \mathrm{hr}$ at $\left.4^{\circ} \mathrm{C}\right)$, rinsed in saline $(0.9 \%)$, stained "en bloc" with magnesium uranyl acelate $(0.5 \%$ in suline for 1 hour at $4^{\circ} \mathrm{C}$, in darkness), rinsed in saline, dehydrated, and embedded in Epok 812 (Ernest F. Fullam, Inc., Schenectady, NY). Cells could be visualized by phase microscopy in the flat disc of Epok 812, and representative areas were cut out and glued onto Epok 812 blocks. Each block contained 30 to 50 cells and at least three blocks were examined at each time point studied. Electron microscopic radioautographs were then prepared according to the flat substrate method of Salpeter and Bachmann (1964). Pale gold sections were placed on collodioncoated glass slides and then coated with a thin film of carbon. The emulsion (Ilford L4) was pipetted onto the slides at a dilution such that a purple interference color was obtained after the slides had dried (usually 1:7 in water). This procedure ensures that there is an evenly packed monolayer of emulsion crystals over the sections. Following an exposure of 4 weeks, slides were developed with D-19 and fixed. The collodion film (containing sections) was then floated off the glass slides, grids (200 mesh) were placed over the sections, and the film was picked up. After removal of the collodion with alcohol, grids were stained with uranyl acetate and lead citrate, and viewed with a JEOL 100 S electron microscope.

Quantification. Electron microscopic radioautographs were quantified according to the method of Williams (1969) in order to determine if any component of the cell was specifically labeled with silver grains. Quantification was only performed on components of the cell body; neurites and growth cones were not systematically con- sidered in this study. The average area occupied by particular cellular components was determined by morphometric analysis (referred to as effective area). This involves overlaying electron micrographs with a regular grid of circles with radii of 1.5 half-distances (HD) and scoring the frequency at which cellular components appear within these circles. The HD of ${ }^{125} \mathrm{I}$ has been determined to be $90 \mathrm{~nm}$ for the radioautographic conditions described above (Salpeter et al., 1977). The cellular components are then assigned a relative specific activity by determining the ratio of the percentage of silver grains found over that component and the percentage of effective area that that component occupies. The grains are allotted to various cellular components by centering one of the circles described above over the grain. If more than one component lies within the circle, grains are then assigned to a single component by taking into account both the area occupied by the components and their relative specific activities, as determined when only single components lie within the circle surrounding the grain. A relative specific activity of 1 indicates that no more silver grains were found over that component than one would expect from a random distribution, while relative specific activities greater than 1 indicate a specific association of silver grains with a cellular component. A $\chi^{2}$ analysis was done to determine if the grain distribution among the different cellular components was random.

An alternative type of analysis was performed to determine the distribution of grains around the plasma membrane and nuclear membrane (Salpeter et al., 1969). The shortest distance from the center of a grain to the membrane was measured and the data were compiled as a histogram.

\section{Results}

Light microscopic radioautography. Observations of light microscopic radioautographs revealed that all PC12 cells incubated with $5 \mathrm{ng} / \mathrm{ml}$ of ${ }^{125} \mathrm{I}-\mathrm{NGF}$ (Fig. 1) bound the factor at all time points studied $(2 \mathrm{~min}, 15 \mathrm{~min}, 1 \mathrm{hr}$, $6 \mathrm{hr}, 24 \mathrm{hr}, 1$ week). The density of ${ }^{125}$ I-NGF binding associated with the cells, however, was significantly greater at all time points in primed cultures (i.e., those previously maintained for 1 week with nonradioactive $\mathrm{NGF}$ and then for $1.5 \mathrm{hr}$ without NGF) than in naive cultures (i.e., NGF untreated; compare Fig. $1 a$ and $b$ to $1 c$ and $d$ ). The distribution of radioautographic grains was uniform over the cell bodies at all times of incubation, as well as over neurites and growth cones (Fig. 1, $a$ to $d$ ), at the shorter incubation times ( $2 \mathrm{~min}, 15 \mathrm{~min}, 1$ $\mathrm{hr}$ ). Following $6 \mathrm{hr}$ of incubation with ${ }^{125} \mathrm{I}-\mathrm{NGF}$, primed cells began to exhibit "hot spots" of grain density along neurites (Fig. 1, $e$ and $f$ ). The pattern of labeling was identical at both lower $\left(2 \mathrm{ng} / \mathrm{ml}\right.$ of $\left.{ }^{125} \mathrm{I}-\mathrm{NGF}\right)$ and higher $\left(10 \mathrm{ng} / \mathrm{ml}\right.$ of ${ }^{125} \mathrm{I}-\mathrm{NGF}$ with $200 \mathrm{ng} / \mathrm{ml}$ of nonradioactive NGF) concentrations of NGF. Control cultures incubated with ${ }^{125}$ I-NGF and a 1000-fold excess of nonradioactive NGF $(5 \mu \mathrm{g} / \mathrm{ml})$ exhibited only background levels of radioautographic grains (Fig. $1 g$ and $h$ ).

Analysis of radioactivity within cells. TCA precipitations of lysed cultures at all time points examined (15 $\min , 1 \mathrm{hr}, 6 \mathrm{hr}, 1$ day) revealed that greater than $97 \%$ of the radioactivity associated with the cells was precipitable. There was no apparent correlation between the 

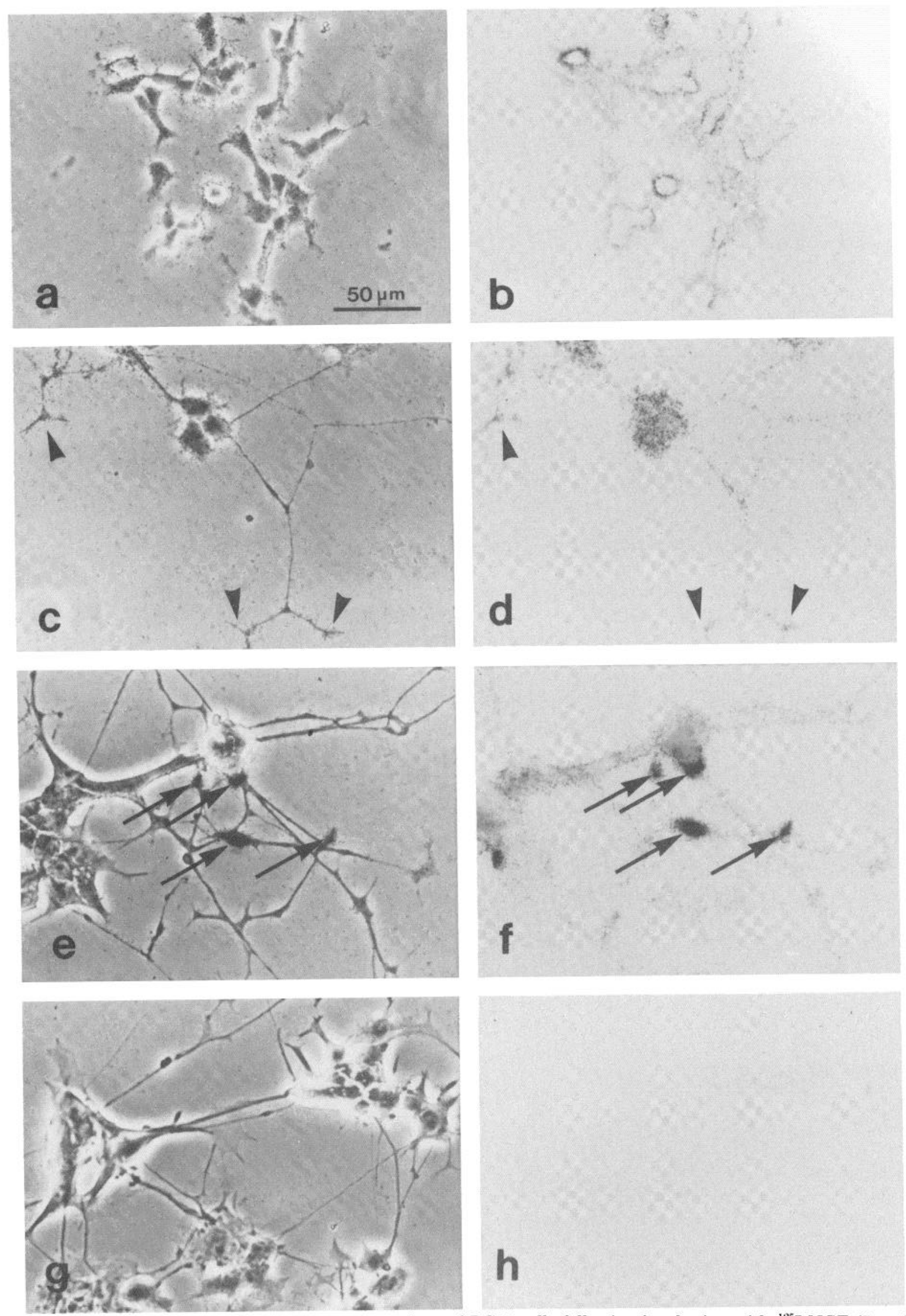

Figure 1. Radioautographs of whole mount preparations of PC12 cells following incubation with ${ }^{125} \mathrm{I}-\mathrm{NGF}(5 \mathrm{ng} / \mathrm{ml})$. Both phase contrast (left) and bright-field (right) images are shown. $a$ and $b$, Naive PC12 cells incubated with ${ }^{125}$ I-NGF for $1 \mathrm{hr}$. Note that all cells are labeled and that the distribution of grains over the cells is uniform, although grains are not necessarily in the 
length of incubation with ${ }^{125} \mathrm{I}-\mathrm{NGF}$ and the amount of precipitable radioactivity. When radioactivity was recovered from the cultures and subjected to gel electrophoresis, it co-migrated with the ${ }^{125} \mathrm{I}-\mathrm{NGF}$ standard (Fig. 2 ), as well as with nonradioactive NGF. There was no detectable radioactivity at the front of the gel. Gamma counting of samples indicated that primed cells specifically bound 3 times more ${ }^{125} \mathrm{I}-\mathrm{NGF}$ per cell $(1.5 \mathrm{fg} / \mathrm{cell})$ than did naive cells at all time points studied.

Electron microscopic radioautography. PC12 cultures incubated with ${ }^{125} \mathrm{I}$-NGF for the various times indicated above were further processed for EM radioautography (see "Materials and Methods"). Morphometric analyses of naive and primed PC12 cells were carried out to facilitate analysis of the data. The proportions of cellular area (effective area) occupied by various cellular com- ponents in the cell body are indicated in Table I. It should be noted that naive and primed cells do not differ considerably in the proportion of the various components they contain; however, the nucleus and polyribosomes appear to occupy a somewhat greater part of the soma in primed cells. It should also be taken into consideration that primed cells are 2- to 3-fold greater in volume than naive cells (Greene and Tischler, 1982), so that the absolute size of the nucleus and the amount of polyribosomes are greater. This is to be expected, since the process of priming (i.e., neurite elongation) involves a considerable amount of protein synthesis.

Analysis of the distribution of silver grains over various cellular components in electron microscopic radioautographs was carried out by the Williams (1969) analysis see ("Materials and Methods" for further detail). At each

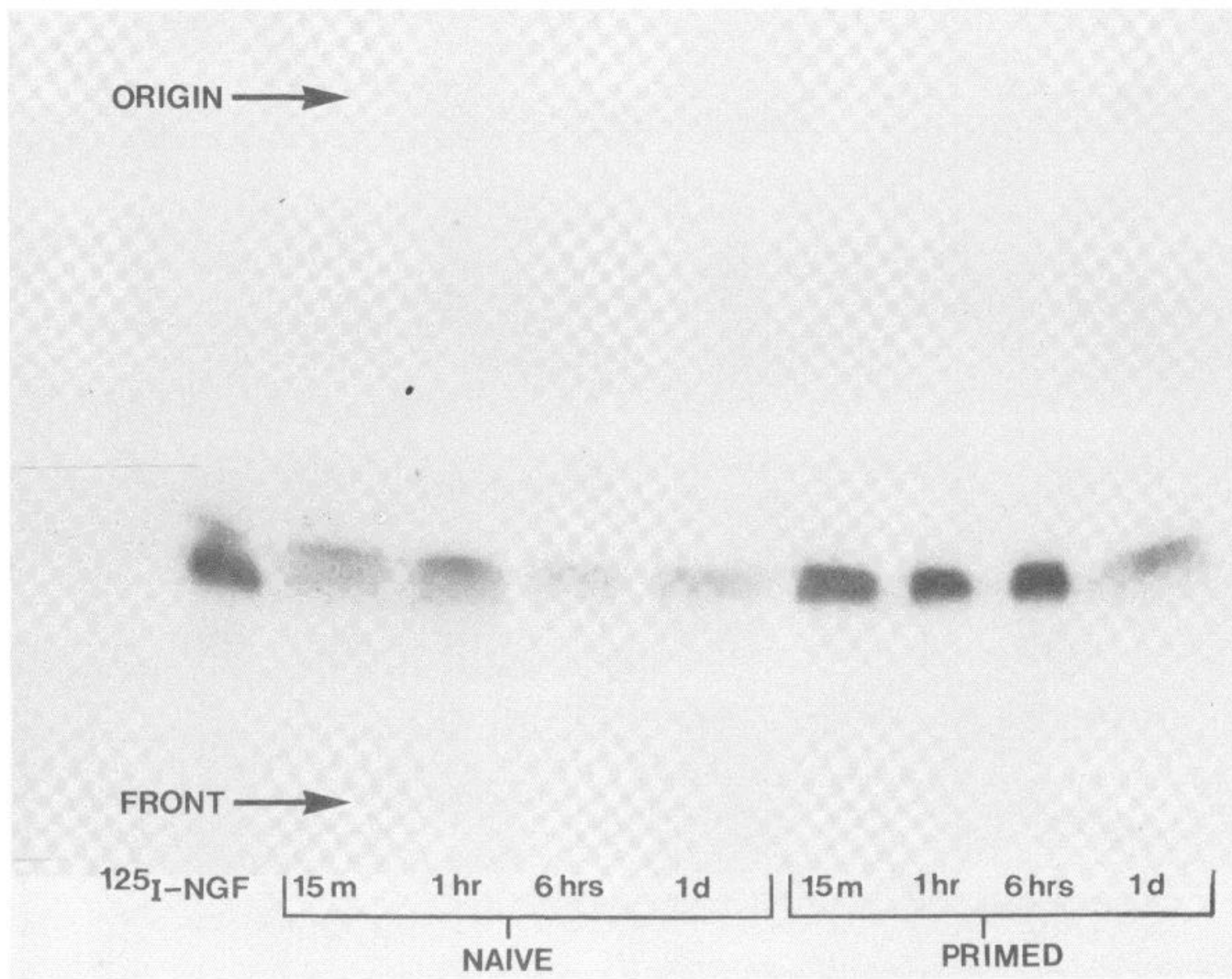

Figure 2. Radioautograph of a $15 \%$ polyacrylamide gel containing samples obtained by harvesting PC12 cells following an incubation with ${ }^{125} \mathrm{I}-\mathrm{NGF}(5 \mathrm{ng} / \mathrm{ml})$ for the lengths of time indicated. Note that the radioactivity present in the cells co-migrated with the ${ }^{125}$ I-NGF standard.

same focal plane. $c$ and $d$, Primed PC12 cells incubated with ${ }^{125} \mathrm{I}-\mathrm{NGF}$ for $1 \mathrm{hr}$. Note the uniform distribution of grains over the cell body, neurites, and growth cones (arrowheads), as well as the increase in grain density as compared to naive cells ( $a$ and $b$ ). $e$ and $f$, Primed PC12 cells incubated with ${ }^{125} \mathrm{I}-\mathrm{NGF}$ for $24 \mathrm{hr}$. Note the appearance of "hot spots" of radioactivity along neurites (arrows). $g$ and $h$, Primed PC12 cells incubated with ${ }^{125} \mathrm{I}-\mathrm{NGF}$ and an excess of nonradioactive NGF (5 $\left.\mu \mathrm{g} / \mathrm{ml}\right)$ for $1 \mathrm{hr}$. Note the absence of labeling. Magnification $\times 320$. 
TABLE I

Effective area occupied by cellular components in the cell bodies of naive and primed PC12 cells

\begin{tabular}{lcc}
\hline & \multicolumn{2}{c}{ Effective Area } \\
\cline { 2 - 3 } & Naive cells $^{a}$ & Primed cells $^{b}$ \\
\hline Heterochromatin & 2.6 & \\
Euchromatin & 17.5 & 2.0 \\
Lysosomes & 0.7 & 0.8 \\
Polyribosomes & 21.8 & 24.5 \\
Cytosol & 56.6 & 50.0 \\
Dense cored granules & 0.3 & 0.3 \\
Plasma membrane & 0.4 & 0.2 \\
Nuclear membrane & 0.2 & 0.1 \\
\hline
\end{tabular}

${ }^{a}$ Effective areas determined from the analysis of 4566 circles.

${ }^{b}$ Effective areas determined from the analysis of 3528 circles.

time point a minimum of 300 grains were scored (approximately 1 to 5 grains/cell). These studies revealed that the only cellular components specifically labeled (i.e., above a random distribution) in naive (Fig. $3 a$ ) and primed (fig. $3 b$ ) cells were the plasma membrane, lysosomes, and nuclear membrane. Representative electron micrographs exhibiting localization of grains over these structures are shown in Figure 4. Note that cytosol, polyribosomes, dense cored granules, heterochromatin, and euchromatin were not specifically labeled. In many cases, the relative specific activity of these components was less than 1, indicating that fewer grains were located over these structures than one would predict from random labeling. Nevertheless, it is apparent from Table II that a large percentage of grains was found over the cytosol and that the nucleus was not devoid of grains, even though these structures showed relative specific activities of less than 1 . The $\chi^{2}$ values are shown in Table III. At all time points studied, there was a nonrandom distribution of grains over the various cellular components $(p<0.0005)$.

The relative specific activities varied with time. For instance, the plasma membrane activity decreased over the first $6 \mathrm{hr}$ of incubation, whereas the proportion of silver grains associated with lysosomes generally increased with time. Especially noticeable in this respect was the marked minimum in relative specific activity of binding to plasma membrane, lysosomes, and nuclear membrane that occurred in naive, but not primed, cells at $6 \mathrm{hr}$ of incubation. Several groups (Calissano and Shelanski, 1980; Yankner and Shooter, 1979) have previously noted that total binding of ${ }^{125}$ I-NGF to naive PC12 cells reaches a maximum after about $1 \mathrm{hr}$ of incubation, is significantly "down-regulated" at 4 to $8 \mathrm{hr}$ of incubation, and then slowly increases to approximately the 1-hr level by $24 \mathrm{hr}$ of incubation. Gamma counting of radioactivity bound to our cultures at various times also confirmed these observations and revealed no down regulation of binding to the primed cultures. It is intriguing that our study reveals apparent changes in binding to naive cells at the 6 -hr time point not only on the cell surface but also in lysosomes and on the nuclear membrane.

The distribution of silver grains within $1 \mu \mathrm{m}$ of the plasma membrane was examined after 2 and $60 \mathrm{~min}$ of incubation with ${ }^{125} \mathrm{I}$-NGF (Fig. 5). It is apparent that after 2 min (Fig $5 a$ ), most of the grains are clustered about the plasma membrane and lie within the first 0.5 $\mu \mathrm{m}$ of the cell surface. Only a small percentage of grains lay further than $1 \mu \mathrm{m}$ from the surface of the cell. If the distribution of grains is compared to the universal curve for an ${ }^{125}$ I line source obtained by Salpeter et al. (1977), it can be estimated that $25 \%$ of the grains are internalized. In contrast, after $60 \mathrm{~min}$ (Fig. $5 b$ ), the grains are found throughout the cell body, and there is only a slight accumulation of grains just underneath the plasma membrane. In order to determine the percentage of grains internalized at the longer time points when ${ }^{125}$ I-NGF is found throughout the cell (i.e., 15 min or longer), electron microscopic radioautographs were analyzed (Williams, $1969)$ and the proportion of grains contained within the cell was compared to the percentage of grains on the surface of the cell. The percentage of grains internalized at the time points studied is shown in Figure 6 . Note that this percentage increases to over $90 \%$ in naive cells and $70 \%$ in primed cells within $15 \mathrm{~min}$.

The distribution of grains about the nuclear membrane was also examined (Fig. 7). The distribution of all grains (Fig. $7 a$ ) indicates that there was a peak centered on the nuclear membrane as well as a cytoplasmic peak at 0.3 $\mu \mathrm{m}(\sim 3 \mathrm{HD})$ from the nucleus. As shown above, the cytosol contains lysosomes that are specifically labeled with grains, and it was possible that radiation derived from these organelles was responsible for the apparent labeling of the nuclear membrane. In order to test this possible influence, grains were eliminated if they were located within $0.3 \mu \mathrm{m}(\sim 3 \mathrm{HD}$, Fig. $7 b)$ or $0.5 \mu \mathrm{m}(\sim 5$ HD, Fig. $7 c$ ) of a lysosome. In addition, grains that were within $0.3 \mu \mathrm{m}$ of the plasma membrane were also discounted (Fig. $7 a$ ). Note that as the lysosomal grains are eliminated (Fig. 7, $b$ and $c$ ), the percentage of grains in the cytosol decreases, whereas the percentage of grains associated with the nuclear membrane persists and becomes the prominent source of radioactive label.

Although electron microscopic quantification was not carried out for neurites of primed cells, it was observed that numerous grains were present within these structures. In particular, it was noted that there was an accumulation of lysosomes along neurites and that, following $24 \mathrm{hr}$ of incubation with ${ }^{125} \mathrm{I}-\mathrm{NGF}$, these lysosomal accumulations were heavily labeled with silver grains (Fig. 8). There was no obvious association of grains with microtubules or microfilaments.

\section{Discussion}

The aim of the present study was to visualize the siles at which NGF associates with PC12 pheochromocytoma cells. To do so, ${ }^{125}$ T-NGF was employed, generally at 5 $\mathrm{ng} / \mathrm{ml}(\sim 0.2 \mathrm{~nm})$. This concentration is near the midpoint of dose-response relationships for a variety of NGF actions on PC12 cells (Greene and Tischler, 1982). Previously, investigators have presented evidence for multiple classes of surface binding sites for NGF, and $5 \mathrm{ng} / \mathrm{ml}$ is near or below the $K_{\mathrm{d}}$ for high affinity sites and well below the $K_{\mathrm{d}}$ for low affinity binding sites in $\mathrm{PC} 12$ and other mammalian preparations (for review, see Bradshaw, 

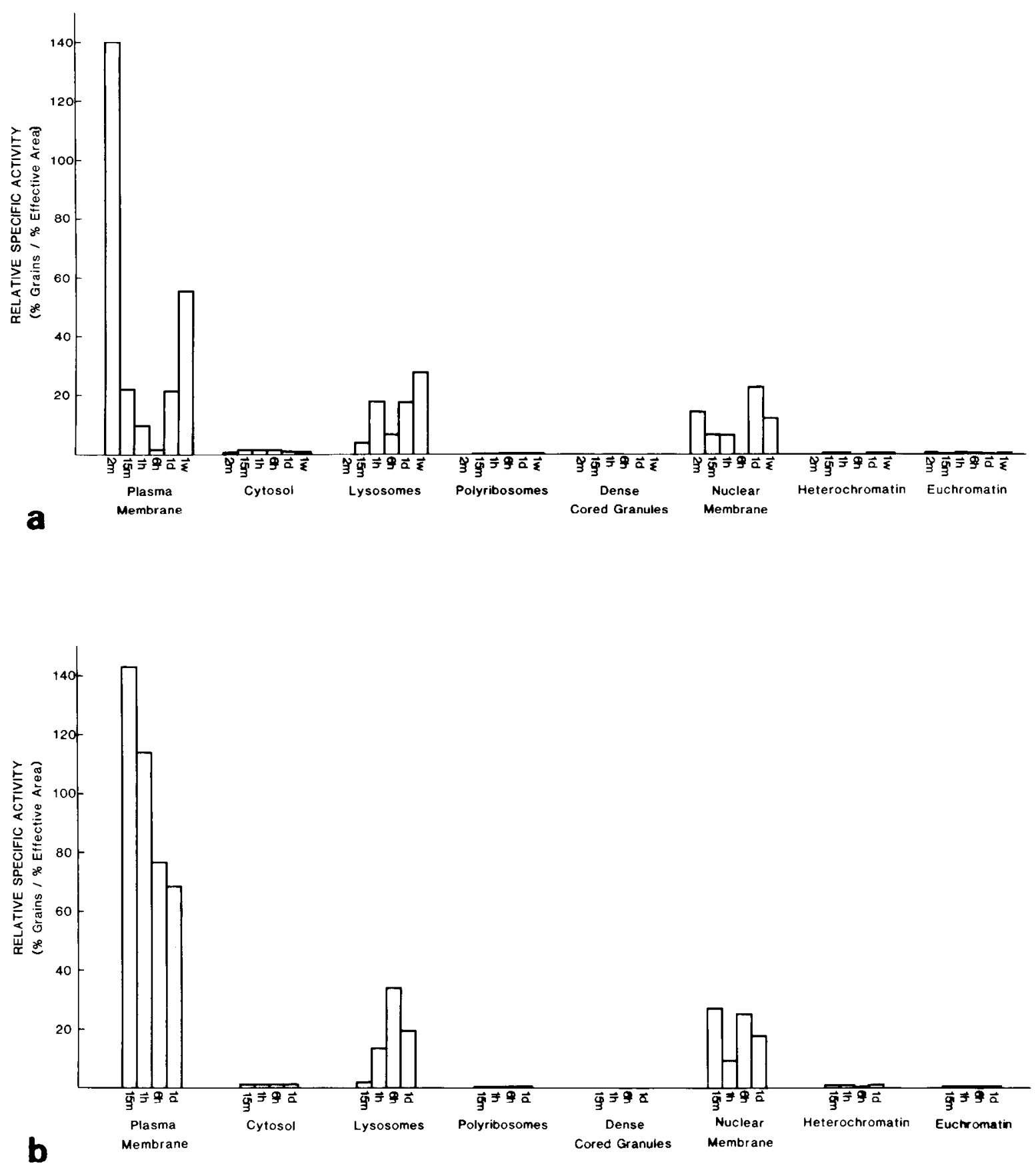

Figure 3. Relative specific activity of cellular components following incubation with ${ }^{125} \mathrm{I}-\mathrm{NGF}(5 \mathrm{ng} / \mathrm{ml}) \mathrm{for}$ the lengths of time indicated. $a$, Naive PC12 cells incubated with ${ }^{125}$ I-NGF for 2 min (139 grains examined), 15 min (313 grains), 1 hr (678 grains), 6 hr (387 grains), 1 day (350 grains), and 1 week (334 grains). b, Primed PC12 cells incubated with ${ }^{125} \mathrm{I}-\mathrm{NGF}$ for 15 min (339 grains), $1 \mathrm{hr}$ (790 grains), $6 \mathrm{hr}$ (405 grains), and 1 day (386 grains). Note that the only significantly labeled structures in both naive and primed cells are the plasma membrane, lysosomes, and nuclear membrane.

1978; Greene and Shooter, 1980). In our experiments, it is noteworthy that similar radioautographic patterns were obtained at the light microscopic level at 2 and 210 $\mathrm{ng} / \mathrm{ml}$ of NGF and at the electron microscopic level (i.e., at the 7 -day point) at $50 \mathrm{ng} / \mathrm{ml}$ of $\mathrm{NGF}$.

Interpretation of radioautographic data requires the assumption that the labeled molecule of interest remains intact. At all time points studied, greater than $97 \%$ of the bound radioactivity recovered from our cultures was
TCA precipitable and co-migrated with authentic NGF by SDS-PAGE in $15 \%$ acrylamide. At the latter acrylamide concentration, smaller TCA-precipitable peptides would have been resolved from NGF. Also, the fixation and processing of the cultures for radioautography would most likely have removed small degradation products. Finally, the observation that the TCA precipitability of the bound radioactivity did not change as a function of time of incubation is further consistent with the absence 

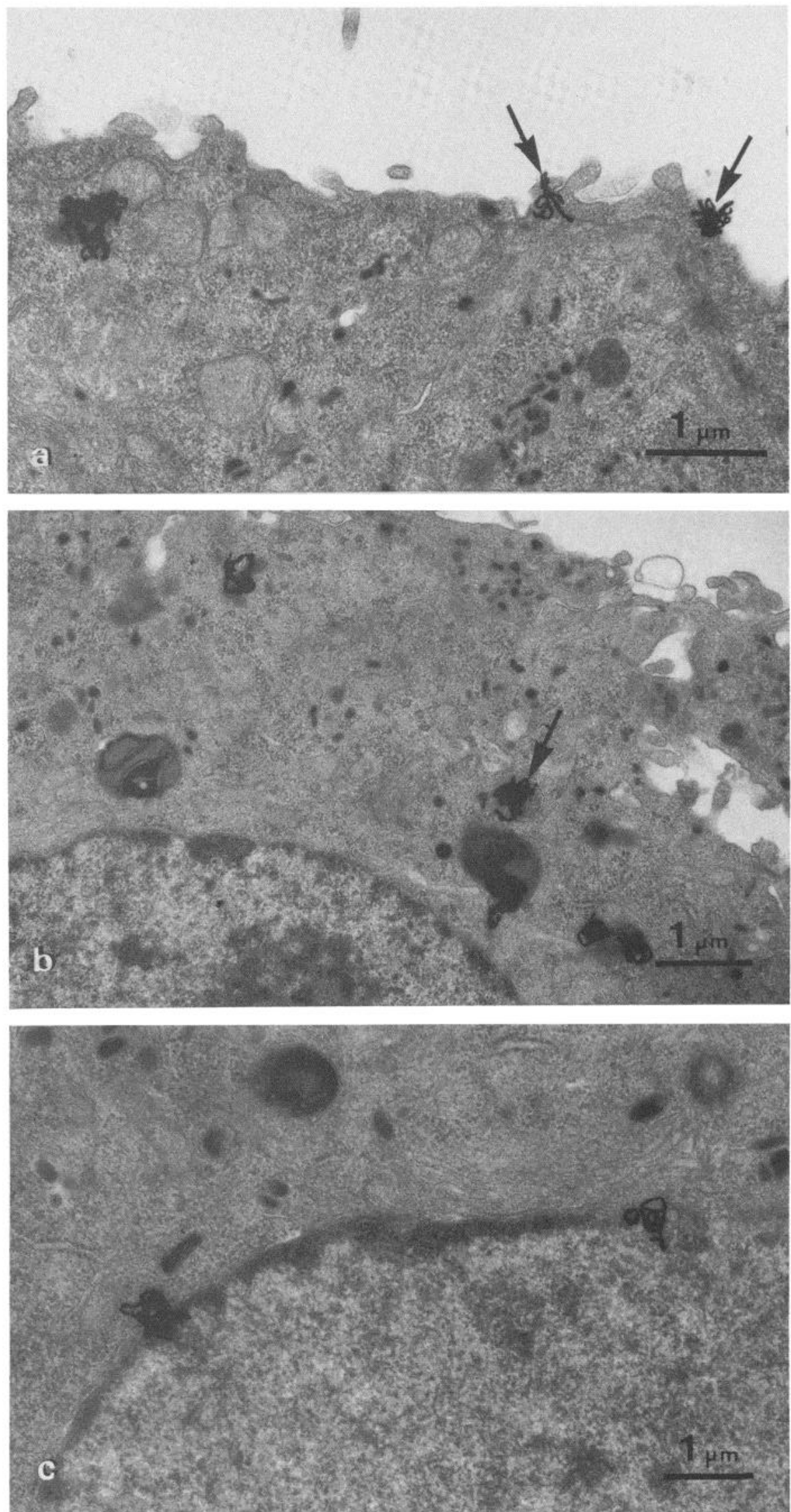

Figure 4. Electron microscopic radioautographs of PC12 cells following incubation with ${ }^{125} \mathrm{I}-\mathrm{NGF}$ (5 ng/ml). $a$, Primed PC12 cells incubated with ${ }^{125} \mathrm{I}-\mathrm{NGF}$ for $1 \mathrm{hr}$. Note the two grains located on the plasma membrane (arrows), as well as the group of three grains located over a lysosome. Magnification $\times 18,750$. $b$, Primed PC12 cells incubated with ${ }^{125} \mathrm{I}-\mathrm{NGF}$ for 6 hr. Note that each grain is located over a lysosomal structure, including a multivesicular body (arrow). Magnification $\times 15,300$. $c$, Primed PC12 cells incubated with ${ }^{125} \mathrm{I}-\mathrm{NGF}$ for $6 \mathrm{hr}$. Note that the two grains in this field are located over the nuclear membrane. Magnification $\times 13,750$ 
TABLE II

Percentage of grains found over cellular components at all time points studied

\begin{tabular}{|c|c|c|c|c|c|c|c|c|c|c|}
\hline & \multicolumn{6}{|c|}{ Naive Cells } & \multicolumn{4}{|c|}{ Primed Cells } \\
\hline & $2 \mathrm{~min}$ & $15 \mathrm{~min}$ & $1 \mathrm{hr}$ & $6 \mathrm{hr}$ & $1 \mathrm{~d}$ & $1 \mathrm{wk}$ & $15 \mathrm{~min}$ & $1 \mathrm{hr}$ & $6 \mathrm{hr}$ & $1 \mathrm{~d}$ \\
\hline Hetercchromatin & 0 & 1.3 & 1.3 & 0 & 1.1 & 1.5 & 2.4 & 1.9 & 0.7 & 1.8 \\
\hline Lysosomes & 0 & 2.9 & 12.8 & 4.7 & 12.3 & 22.2 & 1.5 & 10.6 & 27.2 & 15.5 \\
\hline Polyribosomes & 0.7 & 1.6 & 2.1 & 1.3 & 2.9 & 5.1 & 3.8 & 4.9 & 5.2 & 13.2 \\
\hline Cytosol & 33.8 & 81.5 & 74.2 & 88.9 & 65.4 & 49.4 & 53.7 & 51.4 & 43.0 & 46.9 \\
\hline Dense cored granules & 0 & 0 & 0 & 0 & 0 & 0 & 0 & 0 & 0 & 0 \\
\hline
\end{tabular}

TABLE III

$\chi^{2}$ values determined for the observed number of grains over cellular components as compared to the expected number of grains in the quantification of electron microscopic radioautographs

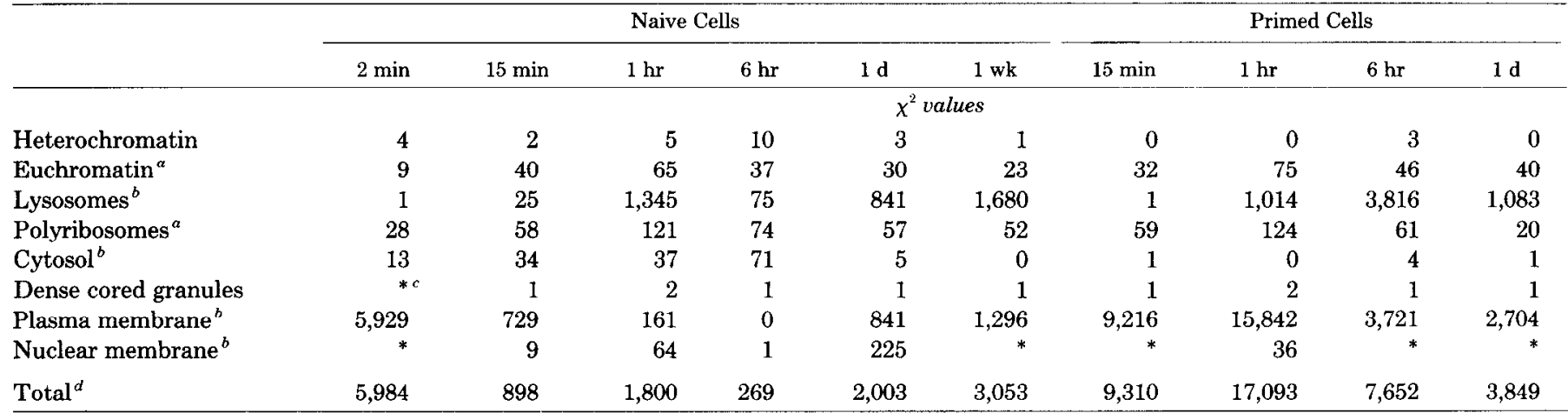

${ }^{a}$ The number of expected grains is significantly more than the number of observed grains at many time points.

${ }^{b}$ The number of observed grains is significantly more than the number of expected grains at many time points.

${ }^{c} *, \chi^{2}$ value could not be determined, because the number of expected grains was zero.

${ }^{d} p<0.0005$ in all cases.

of accumulation of a considerable degree of degradation products within the cells.

Light microscopic radioautography. Light microscopic radioautography revealed several features of interest. First, all cells bound NGF and there appeared to be little difference in labeling from cell to cell within a given culture. Since the naive cells constitute a nonsynchronized proliferating population, this suggests that binding does not vary substantially between various stages of the cell cycle. Second, with the exception of "hot spots" which appeared to correspond to groups of lysosomes, labeling appeared to be more or less uniformly distributed over primed cells. Although systematic quantification was not carried out, the 2- to 5-fold difference in NGF binding density for cell body and neurites previously reported for primary cultures of neurons (Carbonetto and Stach, 1982; Claude et al., 1982) was not evident here. Perhaps NGF receptors do not spatially segregate on PC12 cells (at least after only a week of NGF pretreatment) or the lysosomes of normal neurons are more densely but more uniformly distributed within neurites. A third feature of interest was that primed cells consistently appeared to be more heavily labeled than naive cells at comparable times of incubation up to 24 $\mathrm{hr}$. This was also confirmed by direct counting of specifically bound radioactivity. Since a similar or greater proportion of the NGF bound to primed cells is associated with the plasma membrane (Table II), these findings suggest that NGF may induce its own membrane receptors.

Electron microscopic radioautography. Although a systematic analysis was not carried out, our data nevertheless reveal some information about the route of NGF internalization. For at least several peptide ligands, internalization appears to occur as follows: binding to diffusely localized receptors, clustering of ligand-receptor complexes, endocytosis of complexes via coated pits, formation and pinching off of "receptosomes" from coated pits, and transfer of the contents of receptosomes to lysosomes (Pastan and Willingham, 1981). Studies with fluorescently labeled NGF (Levi et al., 1980) have suggested that NGF internalization follows at least the first three steps of this scheme. Our data indicate that NGF begins to enter lysosomes within 2 to $15 \mathrm{~min}$ of exposure to the cell but that only between 15 and $60 \mathrm{~min}$ do appreciable levels of the factor begin to enter these structures. At all times including 2 and $15 \mathrm{~min}$, moreover, an appreciable amount of internalized NGF appeared within the cytosolic and nuclear compartments (Table II). If NGF is indeed taken up by the above route and a cytoplasmic component has not been overlooked (i.e., receptosomes, microtubules, etc.), then these findings imply that a considerable proportion of the internalized factor avoids or escapes lysosomal degradation. There is precedence for this, for example, in the case of diphtheria toxin (Sandvig and Olsnes, 1981; Keen et al, 1982). It 

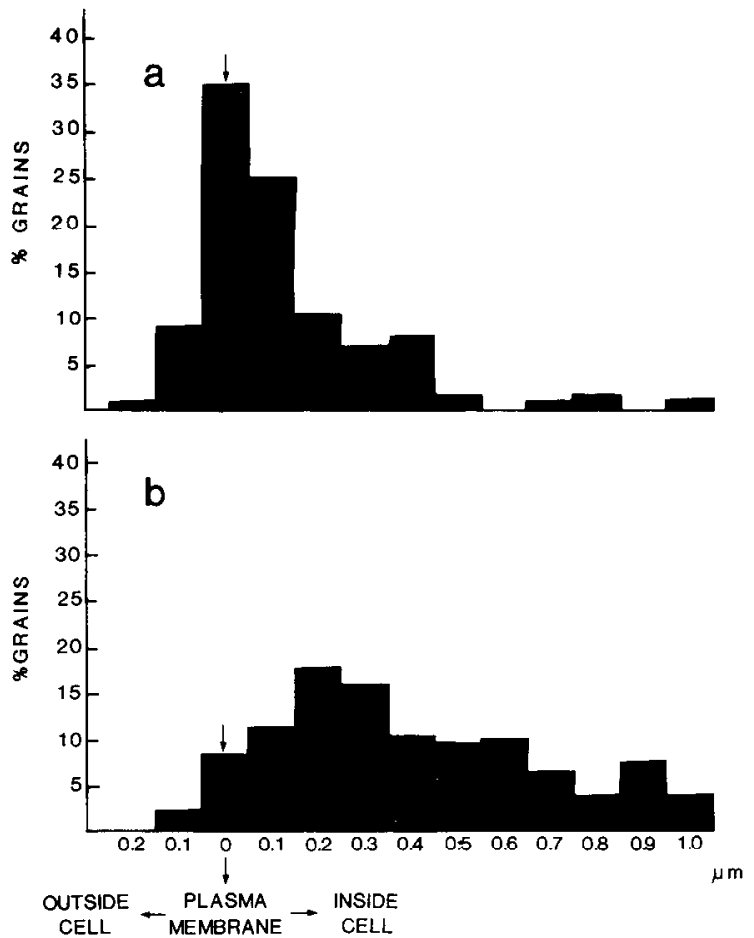

Figure 5. A histogram describing the distribution of grains about the plasma membrane of naive PC12 cells following an incubation with ${ }^{125} \mathrm{I}-\mathrm{NGF}(5 \mathrm{ng} / \mathrm{ml})$. $a, \mathrm{PC} 12$ cells incubated with ${ }^{125} \mathrm{I}-\mathrm{NGF}$ for $2 \mathrm{~min}$ (124 grains examined). $b, \mathrm{PC} 12$ cells incubated with ${ }^{125} \mathrm{I}-\mathrm{NGF}$ for $1 \mathrm{hr}$ (82 grains examined). Note that after a 2-min incubation, most of the grains examined within $1 \mu \mathrm{m}$ of the plasma membrane are localized on or near the plasma membrane, whereas after a 1-hr incubation the grains are more evenly distributed. The half-distance for ${ }^{125} \mathrm{I}$ is equal to $90 \mathrm{~nm}$ for the conditions described.

appears to undergo receptor-mediated endocytosis and subsequently to be released into the cytosol.

An additional point revealed by our data was that a very large proportion (70 to $90 \%$ ) of the NGF associated with the cells beyond 2 min of incubation was intracellular. It is unlikely that this is due to selective displacement of surface-bound NGF during washing prior to fixing, since this procedure was carried out well within $30 \mathrm{sec}$ and with ice-cold buffer. These observations therefore suggest caution in interpretation of kinetic "binding" studies with ${ }^{125} \mathrm{I}$ in which possible internalization has not been assiduously ruled out. Also, these findings suggest that observations in which bound, labeled NGF cannot be competed off by excess unlabeled factor (e.g., "rightly bound" or "sequestered" NGF) may be at least partly due to internalization.

Previous (Yankner and Shooter, 1979; Calissano and Shelanski, 1980) as well as present studies have shown that total binding of ${ }^{125} \mathrm{I}-\mathrm{NGF}$ to naive $\mathrm{PC} 12$ cells undergoes a marked minimum between about 4 and $6 \mathrm{hr}$ of NGF exposure. Our radioautographic data also reveal a minimum in plasma membrane binding at this time. It is intriguing that this effect was accompanied by a drop in association of label with lysosomes and with the nuclear membrane and that only a gradual drop occurred in the case of primed cells. This down-regulation of surface binding has been postulated to arise from receptor-me- diated endocytosis. However, these two processes appear to be dissociable since appreciable internalization of $\mathrm{NGF}$ occurs under conditions in which down-regulation does not appear to take place (primed cells).

Aside from the plasma membrane and lysosomes, the nuclear membrane also revealed significant levels of accumulation of radioactivity. This accumulation was noted both in naive and primed PC12 cells and at times of incubation of as little as 2 to $15 \mathrm{~min}$. The reliability of the Williams (1969) analysis depends in part on the accuracy with which effective area can be determined. Since the nuclear membrane was found to occupy only a very small effective area $(0.2 \%)$, the calculation of relative specific binding to this structure could be open to considerable error. Measurements of the average nuclear diameter in naive $\mathrm{PC} 12$ cells yielded a value of $6.4 \mu \mathrm{m}(N$ $=45$ ) and the published values for the thickness of the nuclear membrane is $29 \mathrm{~nm}$ (Weiss and Greep, 1977). Employing the value for the percentage of effective area of the nucleus given in Table I (20\%), the relative area of of the nuclear membrane can be calculated to be about $0.4 \%$ of the area of the cell in our sections. Even with this value, however, the relative specific binding to the nuclear membrane would be above 1 for most time points studied (see Table II).

Accumulation of label at the nuclear membrane was confirmed by a second approach, not involving determination of effective area, in which the distribution of grains in the region of the nuclear membrane was plotted. This analysis also appeared to rule out radiation from nearby lysosomes or from the plasma membrane as the cause of this accumulation (Fig. 7). It is finally of interest to note that there are several other instances in which peptide hormones have been found to localize on the

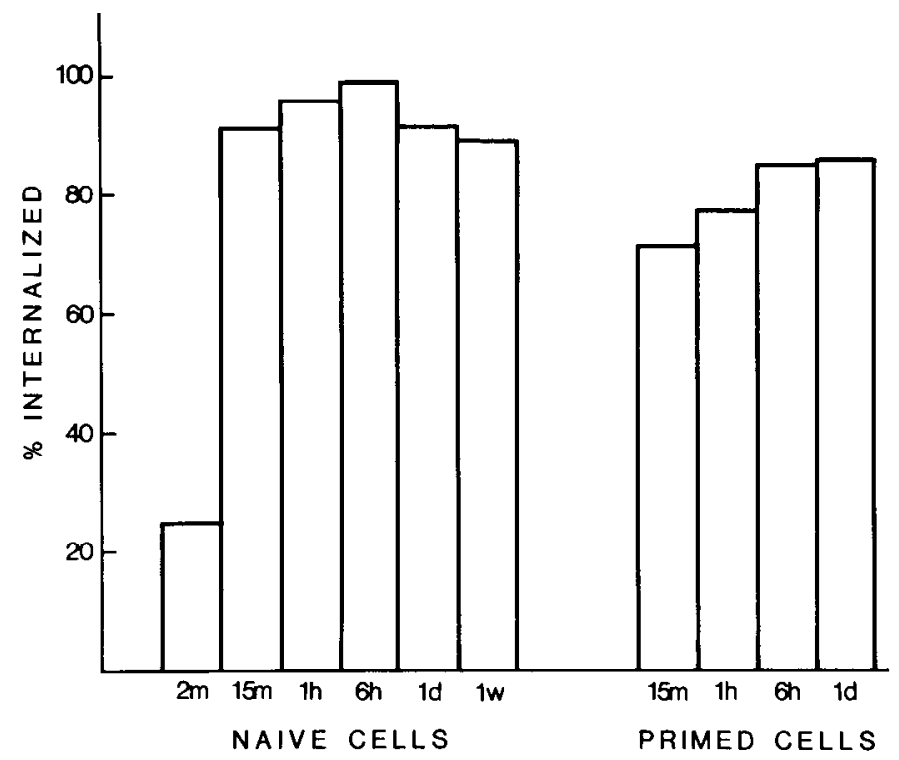

Figure 6. Percentage of ${ }^{125} \mathrm{I}-\mathrm{NGF}$ internalized in naive and primed $\mathrm{PC} 12$ cells following an incubation with ${ }^{125} \mathrm{I}-\mathrm{NGF}$ (5 ng/ $\mathrm{ml})$ for the lengths of time indicated. The percentage internalized after a 2-min incubation was determined by comparison to the universal curve for a ${ }^{125} \mathrm{I}$ line source (Salpeter et al., 1977), while at all other time points the percentage internalized was determined by the Williams analysis (1969). Note that within $15 \mathrm{~min}$, as much as $90 \%$ of the bound factor was internalized. 

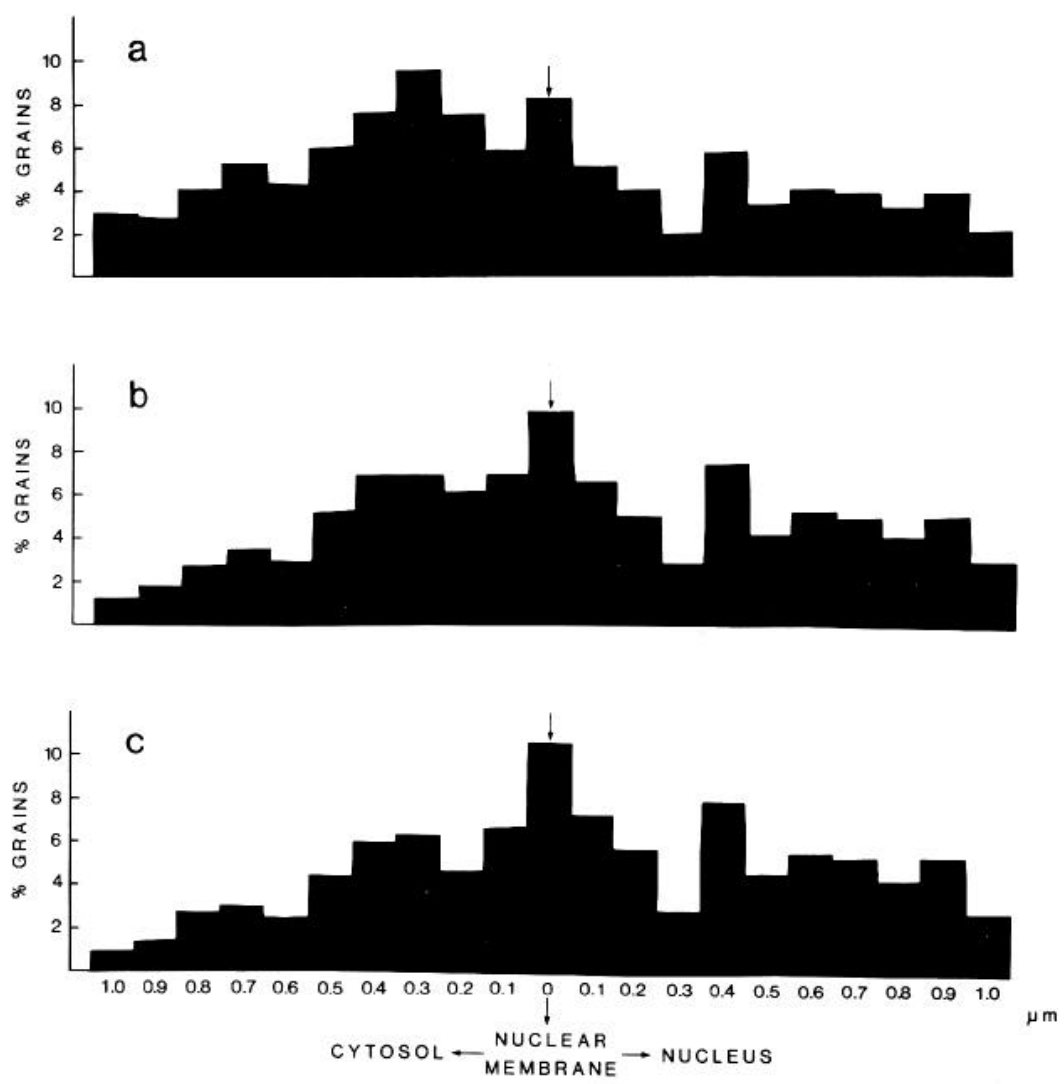

Figure 7. A histogram describing the distribution of grains about the nuclear membrane of PC12 cells incubated with ${ }^{125} \mathrm{I}-\mathrm{NGF}$ $(5 \mathrm{ng} / \mathrm{ml})$ for time periods that exhibited a high relative specific activity (greater than 10; data were pooled from naive cells following a 1-day incubation and from primed cells following incubations of $15 \mathrm{~min}, 6 \mathrm{hr}$, and 1 day). $a$, The distribution of all grains on or near the nuclear membrane, excluding those within $0.3 \mu \mathrm{m}$ of the plasma membrane (579 grains examined). Grain densities were corrected for area changes as the distance from the nuclear membrane increased, and the resulting data were expressed as the percentage of total grains. $b$, The distribution of grains described in $a$, excluding those within $0.3 \mu \mathrm{m}$ of a lysosome (408 grains examined). $c$, the distribution of grains described in $a$, excluding those within $0.5 \mu \mathrm{m}$ of a lysosome (354 grains examined). Note that as grains due to lysosomal sources are removed, the grains associated with the nuclear membrane remain and the level is greater than in the surrounding cytosol or nucleus. The half-distance for ${ }^{125} \mathrm{I}$ is equal to $90 \mathrm{~nm}$ for the conditions described.

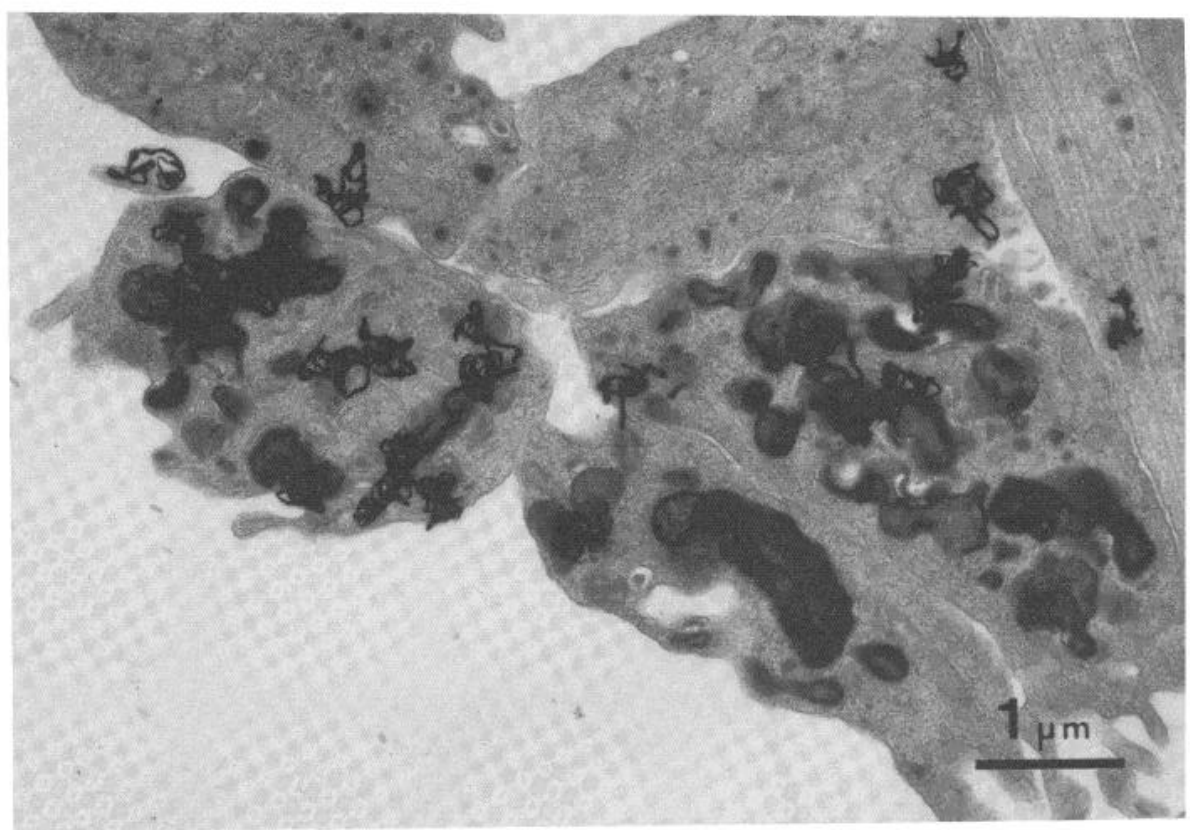

Figure 8. An electron microscopic radioautograph of a neurite of a primed PC12 cell following an incubation with ${ }^{125} \mathrm{I}-\mathrm{NGF}$ (5 $\mathrm{ng} / \mathrm{ml}$ ) for 1 day. Note the intense labeling that occurred in the lysosomal accumulations that were observed along neurites. This appears to correspond to the "hot spots" observed at the light microscopic level (Fig. 1, $e$ and $f$ ). Magnification $\times 15,000$. 
nuclear membrane of their target cells (Goldfine et al., 1978; Johnson et al, 1980).

Comparison with previous studies. Our findings corroborate the many previous biochemical and morphological studies indicating that NGF is internalized by its target cells. The present studies, however, contain both similarities to and differences from other experiments with PC12 cells and cultured neurons. In a light microscopic study, Marchisio et al. $(1980,1981)$ reported a perinuclear distribution of NGF localization within PC12 cells and sympathetic neurons. This could correspond to the peak of lysosomally associated NGF that we noted at about 0.3 to $0.4 \mu \mathrm{m}$ from the nucleus. The former study also described localization of NGF over nucleoli in PC12 cultures. Our data do not confirm this but rather are in agreement with the absence of nuclear or nucleolar accumulation reported with chick (Marchisio et al., 1981) and rat (Schwab and Thoenen, 1977; Claude et al., 1982) sympathetic neurons.

Claude et al. (1982) recently reported the EM localization of ${ }^{125} \mathrm{I}$-NGF within well established cultures of cultured rat sympathetic neurons. While lysosomal accumulation was evident, there was little radioactivity in the nucleus and none detected on the nuclear membrane. The latter difference from our findings could be due in part to variations in procedures. For instance, with the cultured neurons, localization over the nucleus was analyzed following $8 \mathrm{hr}$ of retrograde transport. Alternatively, intracellular localization of NGF in PC12 cells may be fundamentally different from that in postmitotic sympathetic neurons. One can only speculate at present as to the possible significance of such a difference.

On the biochemical side, our findings generally agree with reports regarding the presence of NGF in the nuclear compartment. Proteins of the molecular weight of NGF $(27,000)$ have been found to have free access to the nucleus via diffusion through nuclear pores (Stacey and Allfrey, 1976; Kulka and Loyter, 1979). If NGF does indeed enter the cytosol, then its presence in the nucleus at random or near-random levels is not unexpected. Our values for the proportion of intracellular NGF associated with the nucleus are in general agreement with those reported for neurons (Stockel et al., 1976; Andres et al., 1977; Johnson et al., 1978) but are considerably lower than the value of up to $60 \%$ determined by Yankner and Shooter (1979) for naive PC12 cells.

Models for NGF's site of action. The site of action of NGF constilutes a major issue. Although evidence has been presented to support the possibility that NGF promotes at least some of its activities entirely by means of binding to cell surface receptors (Frazier et al., 1973; Heumann et al., 1981), in our opinion the range and complexity of NGF's actions still leave open the possibility of a mechanistic role for the internalized factor. If, as has been suggested, target neurons derive a major portion of their NGF by uptake and retrograde transport from the periphery (Varon and Bunge, 1978; Thoenen and Barde, 1980), then the internalized factor must be of biological significance and ultimately must reach an appropriate locus of action. Several models regarding a role for internalized NGF have been put forth. For instance, it has been postulated, on the basis of the interaction of NGF with tubulin and actin, that NGF may bind directly to cytoskeletal elements and promote their assembly and/or stabilization (Nasi et al., 1982). However, in our studies such a localization was not manifestly evident, and if such interactions were to occur, they would appear to do so at "substoichiometric" (Nasi et al., 1982) levels. As noted above, NGF has also been reported to interact with the nucleus and has been postulated to act via specific binding sites on either the chromatin (Andres et al., 1977) or nuclear membrane (Yankner and Shooter, 1979). Our data are more consistent with the latter possibility. Finally, since a fair proportion of the internalized NGF appears to escape rapid lysosomal degradation, it is conceivable that the internalized factor could also leave the cell and re-interact with surface receptors. In this case, the internalized NGF could function as a reservoir to buffer the cell from rapid alterations of NGF concentration in the local environment.

Note added in proof. Since the writing of this work, two additional papers dealing with the internalization of ${ }^{125}$ I-NGF by PC12 cells have appeared (Hogue-Angeletti et al., 1982; Rohrer et al., 1982). It should be noted that the results of these studies differ to some degree from our findings.

\section{References}

Andres, R. Y., I. Jeng, and R. A. Bradshaw (1977) Nerve growth factor receptors: Identification of distinct classes in plasma membranes and nuclei of embryonic dorsal root neurons. Proc. Natl. Acad. Sci. U. S. A. 74: 2785-2789.

Bornstein, M. B. (1958) Reconstituted rat-tail collagen used as a substrate for tissue cultures on coverslips in Maximow slides and roller tubes. Lab. Invest. 7: 134-140.

Bradshaw, R. A. (1978) Nerve growth factor. Annu. Rev. Biochem. 47: 191-216.

Calissano, P., and M. L. Shelanski (1980) Interaction of nerve growth factor with pheochromocytoma cells: Evidence for tight binding and sequestration. Neuroscience 5: 1033-1039.

Carbonetto, S., and R. W. Stach (1982) Localization of nerve growth factor bound to neurons growing nerve fibers in culture. Dev. Brain Res. 3: 463-473.

Claude, P., E. Hawrot, D. A. Dunis, and R. B. Campenot (1982) Binding, internalization, and retrograde transport of ${ }^{125} \mathrm{I}$ Nerve Growth Factor in cultured rat sympathetic neurons. J. Neurosci. 2: 431-442.

Frazier, W. A., L. F. Boyd, and R. A. Bradshaw (1973) Interaction of nerve growth factor with surface membranes: Biological competence of insolubilized nerve growth factor. Proc. Natl. Acad. Sci. U. S. A. 70: 2931-2935.

Goldfine, I. D., A. I. Jones, G. T. Hradek, K. Y. Wong, and J. S. Mooney (1978) Entry of insulin into human cultured lymphocytes: Electron microscopic autoradiographic analysis. Science 202: 760-763.

Gottlieb, D. I., and L. Glaser (1975) A novel assay of neuronal cell adhesion. Biochem. Biophys. Res. Commun. 63: 815-821.

Greene, L. A. (1977) A quantitative bioassay for nerve growth factor (NGF) activity employing a clonal pheochromocytoma cell line. Brain Res. 133: 350-353.

Greene, L. A., and E. M. Shooter (1980) The nerve growth factor: Biochemistry, synthesis, and mechanism of action. Annu. Rev. Neurosci. 3: 353-402.

Greene, L. A., and A. S. Tischler (1976) Establishment of a noradrenergic clonal line of rat adrenal pheochromocytoma cells which respond to nerve growth factor. Proc. Natl. Acad. Sci. U. S. A. 73: 2424-2428.

Greene, L. A., and A. S. Tischler (1982) PC12 pheochromocytoma cultures in neurobiological research. In Advances in 
Cellular Neurobiology, S. Fedoroff and L. Hertz, eds., Vol. 3, pp. 373-414, Academic Press, Inc., New York.

Heumann, R., M. Schwab, and H. Thoenen (1981) A second messenger required for nerve growth factor biological activity. Nature 292: 838-840.

Hogue-Angeletti, R., A. Stieber, and N. K. Gonatas (1982) Endocytosis of nerve growth factor by $\mathrm{PC} 12$ cells studied by quantitative ultrastructural autoradiography. Brain Res. 241: $145-156$

Johnson, E. M., Jr., R. Y. Andres, and R. A. Bradshaw (1978) Characterization of the retrograde transport of nerve growth factor (NGF) using high specific activity $\left[{ }^{125} \mathrm{I}\right] \mathrm{NGF}$. Brain Res. 150: 319-331.

Johnson, L. K., I. Vlodavsky, J. D. Baxter, and D. Gospodarowicz (1980) Nuclear accumulation of epidermal growth factor in cultured rat pituitary cells. Nature 287: 340-343.

Keen, J. H., F. R. Maxfield, M. C. Hardegree, and W. H. Habig (1982) Receptor-mediated endocytosis of diphtheria toxin by cells in culture. Proc. Natl. Acad. Sci. U. S. A. 79: 2912-2916.

Kulka, R. G., and A. Loyter (1979) The use of fusion methods for the microinjection of animal cells. In Current Topics in Membranes and Transport, F. Bronner and A. Kleinzeller, eds., Vol. 12, pp. 365-430, Academic Press, Inc., New York.

Laemmli, U. K. (1970) Cleavage of structural proteins during the assembly of the head of bacteriophage 'T'4. Nature 227: $680-685$

Levi, A., Y. Shechter, E. J. Neufeld, and J. Schlessinger (1980) Mobility, clustering, and transport of nerve growth factor in embryonal sensory cells and in a sympathetic neuronal cell line. Proc. Natl. Acad. Sci. U. S. A. 77: 3469-3473.

Levi-Montalcini, R., and P. U. Angeletti (1968) Nerve growth factor. Physiol. Rev. 48: 534-569.

Marchisio, P. C., L. Naldini, and P. Calissano (1980) Intracellular distribution of nerve growth factor in rat pheochromocytoma PC12 cells; Evidence for a perinuclear and intranuclear location. Proc. Natl. Acad. Sci. U. S. A. 77: 1656-1660.

Marchisio, P. C., D. Cirillo, L. Naldini, and P. Calissano (1981) Distribution of nerve growth factor in chick embryo sympathetic neurons in vitro. J. Neurocytol. 10: 45-55.

McGuire, J. C., and L. A. Greene (1980) Stimulation by nerve growth factor of specific protein synthesis in rat $\mathrm{PC} 12$ pheochromocytoma cells. Neuroscience 5: 179-189.

Mobley, W. C., A. Schenker, and E. M. Shooter (1976) Characterization and isolation of proteolytically modified nerve growth factor. Biochemistry 15: 5543-5551.

Nasi, S., D. Cirillo, L. Naldini, P. C. Marchisio, and P. Calissano (1982) Microtubules and microfilaments in fixed and permeabilized cells are selectively decorated by nerve growth factor. Proc. Natl. Acad. Sci. U. S. A. 79: 820-824.

Pastan, I. H., and M. C. Willingham (1981) Journey to the center of the cell: Role of the receptosome. Science 214: 504509.

Rohrer, H., T. Schäfer, S. Korsching, and H. Thoenen (1982) Internalization of nerve growth factor by pheochromocytoma
PC12 cells: Absence of transfer to the nucleus. J. Neurosci. 2: 687-697.

Salpeter, M. M., and L. Bachmann (1964) Autoradiography with the electron microscope. A procedure for improving resolution, sensitivity and contrast. J. Cell Biol. 22: 469-477.

Salpeter, M. M., L. Bachmann, and E. E. Salpeter (1969) Resolution in electron microscope radioautography. J. CeIl Biol. 41: 1-20.

Salpeter, M. M., H. C. Fertuck, and E. E. Salpeter (1977) Resolution in electron microscope autoradiography. III. Iodine-125, the effect of heavy metal staining and a reassessment of critical parameters. J. Cell Biol. 72: 161-173.

Sandvig, K., and S. Olsnes (1981) Rapid entry of nicked diphtheria toxin into cells at low $\mathrm{pH}$. Characterization of the entry process and effects of low $\mathrm{pH}$ on the toxin molecule. J. Biol. Chem. 256: 9068-9076.

Schwab, M. E. (1977) Ultrastructural localization of a nerve growth factor-horseradish peroxidase coupling product after retrograde axonal transport in adrenergic neurons. Brain Res. 130: 190-196.

Schwab, M. E., and H. Thoenen (1977) Selective trans-synaptic migration of tetanus toxin after retrograde axonal transport in peripheral sympathetic nerves: A comparison with nerve growth factor. Brain Res. 122: 459-474.

Stacey, D. W., and V. G. Allfrey (1976) Nuclear penetration and lysosomal degradation of microinjected proteins in living HeLa cells. J. Cell Biol. 70: 3a.

Stockel, K., G. Guroff, M. Schwab, and H. Thoenen (1976) The significance of retrograde axonal transport for the accumulation of systemically administered nerve growth factor (NGF) in the rat superior cervical ganglion. Brain Res. 109: 261-284.

Sutter, A., R. J. Riopelle, R. M. Harris-Warrick, and E. M. Shooter (1979) Nerve growth factor receptors. Characterization of two distinct classes of binding sites on chick embryo sensory ganglia cells. J. Biol. Chem. 254: 5972-5982.

Thoenen, H., and Y. A. Barde (1980) Physiology of nerve growth factor. Physiol. Rev. 60: 1284-1335.

Tischler, A. S., and L. A. Greene (1975) Nerve growth factorinduced process formation by cultured rat pheochromocy. toma cells. Nature 258: 341-342.

Varon, S. S., and R. P. Bunge (1978) Trophic mechanisms in the peripheral nervous system. Annu. Rev. Neurosci. 1: 327361.

Weiss, L., and R. O. Greep (1977) Histology, Ed. 4, McGrawHill Book Co., New York.

Williams, M. A. (1969) The assessment of electron microscopic autoradiographs. In Advances in Optical and Electron $\mathrm{Mi}$. croscopy, R. Barer and V. E. Cosslett, eds., Vol. 3, pp. 219272, Academic Press, Inc., New York.

Yankner, B. A., and E. M. Shooter (1979) Nerve growth factor in the nucleus: Interaction with receptors on the nuclear membrane. Proc. Natl. Acad. Sci. U. S. A. 76: 1269-1273. 